Ю. К. Корніснко ${ }^{\bowtie}$ Ю. С. Федченко, Ф. А. Тріиин

Одеська національна академія харчових технологій, вул. Канатна, 112, м. Одеса, 65039, Україна

$\triangle$ e-mail: yurikkorn@gmail.com, ORCID: orcid.org/0000-0002-0973-3927

\title{
ВИКОРИСТАННЯ ДИСТАНЦІЙНИХ ТЕХНОЛОГІЙ ЯК ЗАСІБ ПІДВИЩЕННЯ ЯКОСТІ НАВЧАННЯ
}

Стаття присвячена досвіду впровадження і використання системи підтримки навчання на базі Moоdle, яка створена і використовується в Одеській національній академії харчових технологій з 2014 р. Відмічається, що на даному етапі використання ия система на базі Моодlе застосовується в академї для підтримки традииійного навчання як денної, так $і$ заочної форм навчання, зокрема для організаиії самостійної роботи студентів. Особлива увага приділяється тестовому контролю знань. Аналізується якість створення тестових завдань, наводяться параметри якості, пропонуються засоби покращчити ичю якість. Останне можна зробити, в тому числі, за допомогою використання зовнішніх ресурсів в системі Моодle, наприклад, за допомогою онлайнpecypcy LearningApps.org.

Ключові слова: Дистаниійне навчання; Інформатизація освіти; Комп'ютеризація освіти; Тестовий контроль; Система Moоdle; Аналіз структури тесту.

Ю. К. Корниенко, Ю. С. Федченко, Ф. А. Трииин

Одесская национальная академия пищевых технологий, ул. Канатная, 112, Одесса, 65039, Украина

\section{ИСПОЛЬЗОВАНИЕ ДИСТАНЦИОННЫХ ТЕХНОЛОГИЙ КАК СРЕДСТВА ПОВЫШЕНИЯ КАЧЕСТВА ОБУЧЕНИЯ}

Статья посвящена опыту внедрения и использования системы поддержки обучения на базе Moоdle, которая создана и используется в Одесской национальной академии пищевых технологий с 2014 года. Отмечается, что на данном этапе использования эта система на базе Моодlе применяется в академии для поддержки традиционного обучения как дневной, так и заочной форм обучения, в частности для организации самостоятельной работы студентов. Особое внимание уделяется тестовому контролю знаний. Анализируется качество создания тестовых заданий, приводятся параметры качества, предлагаются средства улучшить это качество. Последнее можно сделать, в том числе, посредством использования внешних ресурсов в системе Moоdle, например, с помощью онлайн-ресурса LearningApps.org.

Ключевые слова: Дистанџионное обучение; Информатизаџия образования; Компьютеризация образования; Тестовый контроль; Система Mоодlе; Анализ структуры теста.

This work is licensed under the Creative Commons Attribution International License (CC BY). http://creativecommons.org/licenses/by/4.0/

\section{І. ВСТУП}

За останні роки стрімкий розвиток інформаційних технологій зробив актуальною проблему модернізації системи освіти. Суть такої модернізації знайшла найбільше відображення в концепції дистанційного навчання (ДН), яка, завдяки такому глобальному явищу як Інтернет, охоплює широкі шари суспільства та стає найважливішим фактором його розвитку [1].

Новітні інформаційні технології відкривають нові перспективи для підвищення ефективності та якості освітнього процесу. Велика роль надається дистанційним освітнім програмам, які надають можливість індивідуалізувати процес набуття знань, умінь, навичок і способів пізнавальної діяльності людини [2]. Ці програми відбуваються, в основному, за опосередкованої взаємодії віддалених один від одного учасників навчального процесу у спеціалізованому середовищі, що функціонуе на базі сучасних психологопедагогічних та інформаційно-комунікаційних технологій.

Одним із засобів інформаційно-комунікаційних технологій, що відповідає зазначеним умовам, $\epsilon$ Еlearning - платформа Moodle, яка $є$ вільно поширюваною системою управління навчальним контентом [3].

Система Moodle $є$ одною з найбільш розвинених систем електронного навчання, що має багатомовний інтерфейс, надає можливість організувати повноцінний навчальний процес, включаючи засоби навчання, систему контролю й оцінювання навчальної діяльнос- 
ті студентів, а також інші необхідні складові системи підтримки навчального процесу.

\section{II. ДОСВІД ВПРОВАДЖЕННЯ СИСТЕМИ ПІДТ- РИМКИ НАВЧАННЯ НА БАЗІ МООDLЕ}

В ОНАХТ впровадження технологій дистанційного навчання на основі системи Moodle у навчальний процес почалося зі створення у лютому 2014 року Центру дистанційного навчання. Був розроблений сайт цього Центру за електронною адресою: http://moodle.onaft.edu.ua/ (рисунок 1), підготовлені та затверджені нормативні документи, які регламентують діяльність Центру, а саме - Положення про дистанційне навчання в ОНАХТ; Положення про Центр дистанційного навчання в ОНАХТ [7].

\section{Центр дистапційного навчания ОНАХТ (дистапційпі курси)}
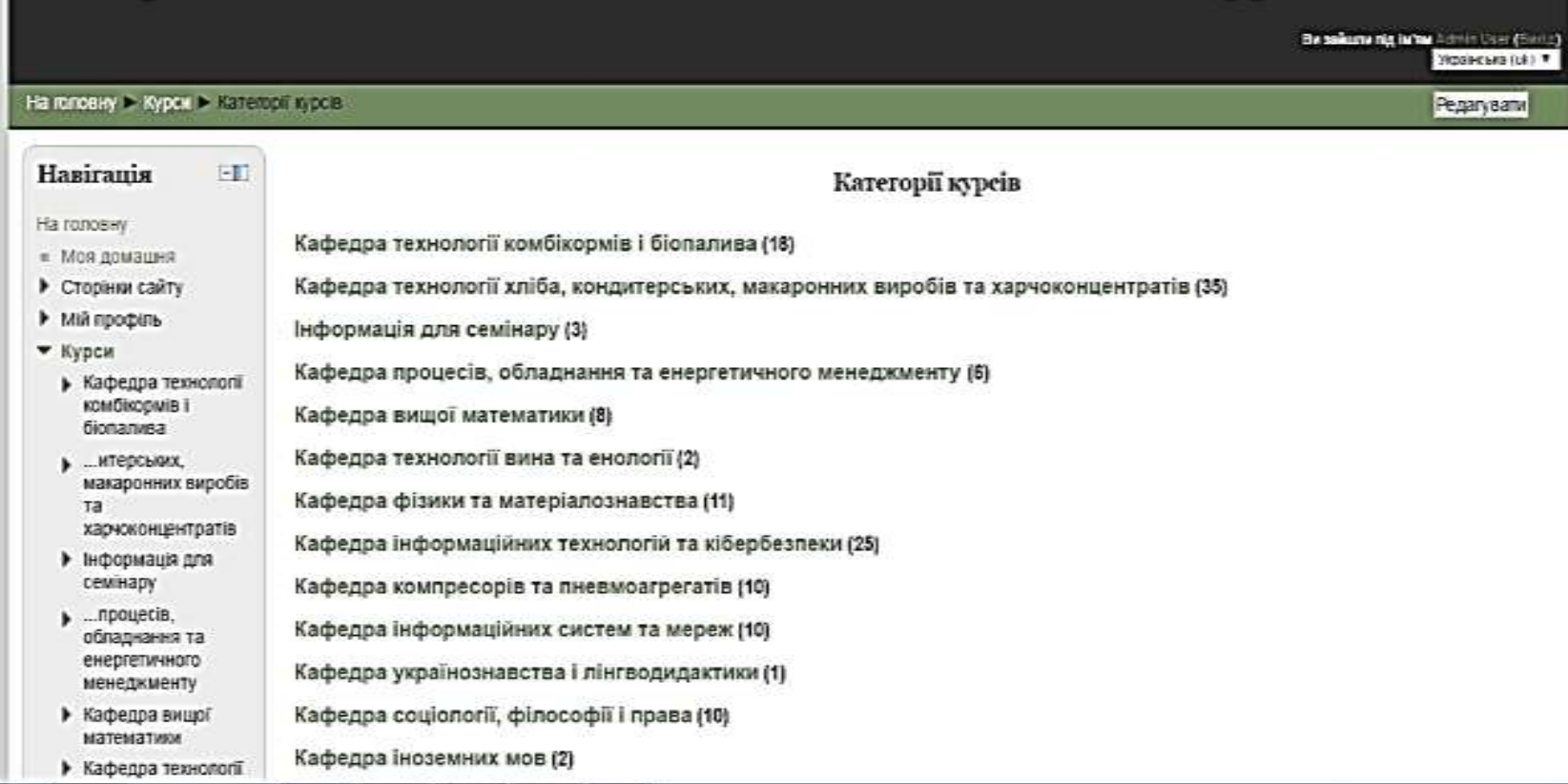

Категорй қуреів

Рисунок 1 - Сторінка сайту Центру дистанційного навчання ОНАХТ

Було встановлено програмне середовище Moodle на сервері хостингу, забезпечена можливість реєстрації розробників дистанційних курсів. На базі факультету інформаційних технологій та кібербезпеки створили робочу групу по розробці дистанційних курсів та наданню консультацій розробникам дистанційних курсів, створили список першочергових дисциплін для впровадження технологій дистанційного навчання на факультеті інформаційних технологій та кібербезпеки. Пізніше до цієї діяльності залучилися викладачі інших факультетів академіі.

При розробленні дидактичних матеріалів для дистанційних курсів враховувались наступні вимоги:

1) навчальні матеріали дистанційного курсу мають бути складені таким чином, щоб мінімізувати звертання студента до додаткової навчальної інформації;

2) обов'язковий поділ навчального матеріалу дисципліни, яка вивчається, на навчальні одиниці (модулі);
3) повинні бути проведені докладні інструкції 3 вивчення матеріалу й організації самостійної роботи;

4) обов'язковими елементами в навчальних матеріалах мають бути контрольні (тестові) завдання [4, 5], тлумачні словники, питання для самоперевірки, тренувальні завдання, довідкова система у вигляді бази даних до всього навчального курсу.

Всі дистанційні курси були зроблені та розміщені на сайті дистанційного навчання ОНАХТ. На рисунку 2 наведений приклад дисципліни «Фізика». Кожний курс включає поділені на окремі тижні електронні варіанти лекцій, матеріали до лабораторних або практичних занять, термінологічні словники, пакети тестових завдань для проведення контрольних заходів 3 можливістю автоматизованої перевірки результатів знань студентів за кожною темою. Для завдань можуть визначатися термін здачі, максимальна оцінка, студенти можуть закачувати відповіді на завдання в систему, де автоматично записується витрачений на виконання завдань час. 


\section{Фізика (Корнієнко)}

\section{6 sересен - a2 вересен}

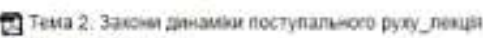

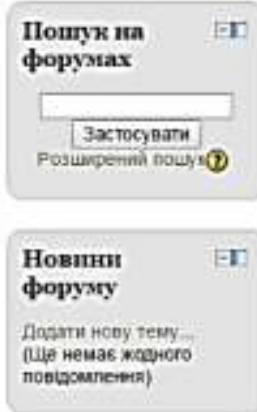

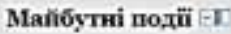

Hewac nouly y

мaйoyтmöy

Стерити saxia.

Останні

Рисунок 2 - Сторінка курсу «Фізика»

У системі підтримуються різні види питань: правильно/неправильно, множинний вибір одного або вибір декількох варіантів, коротка відповідь, числовий, відповідність (всі ці види тестів в системі автоматично оцінюються), питання у відкритій формі (есе, оцінюються власноруч викладачем). Тести можуть мати обмежені тимчасові рамки та інші налаштуван- ня. Доступним є повний звіт щодо входження користувача до системи і його активності з графіками та деталями роботи 3 різними модулями (останній вхід, кількість прочитаного, повідомлення та інша інформація). На рисунку 3 наведений фрагмент тесту 3 множинним вибором.

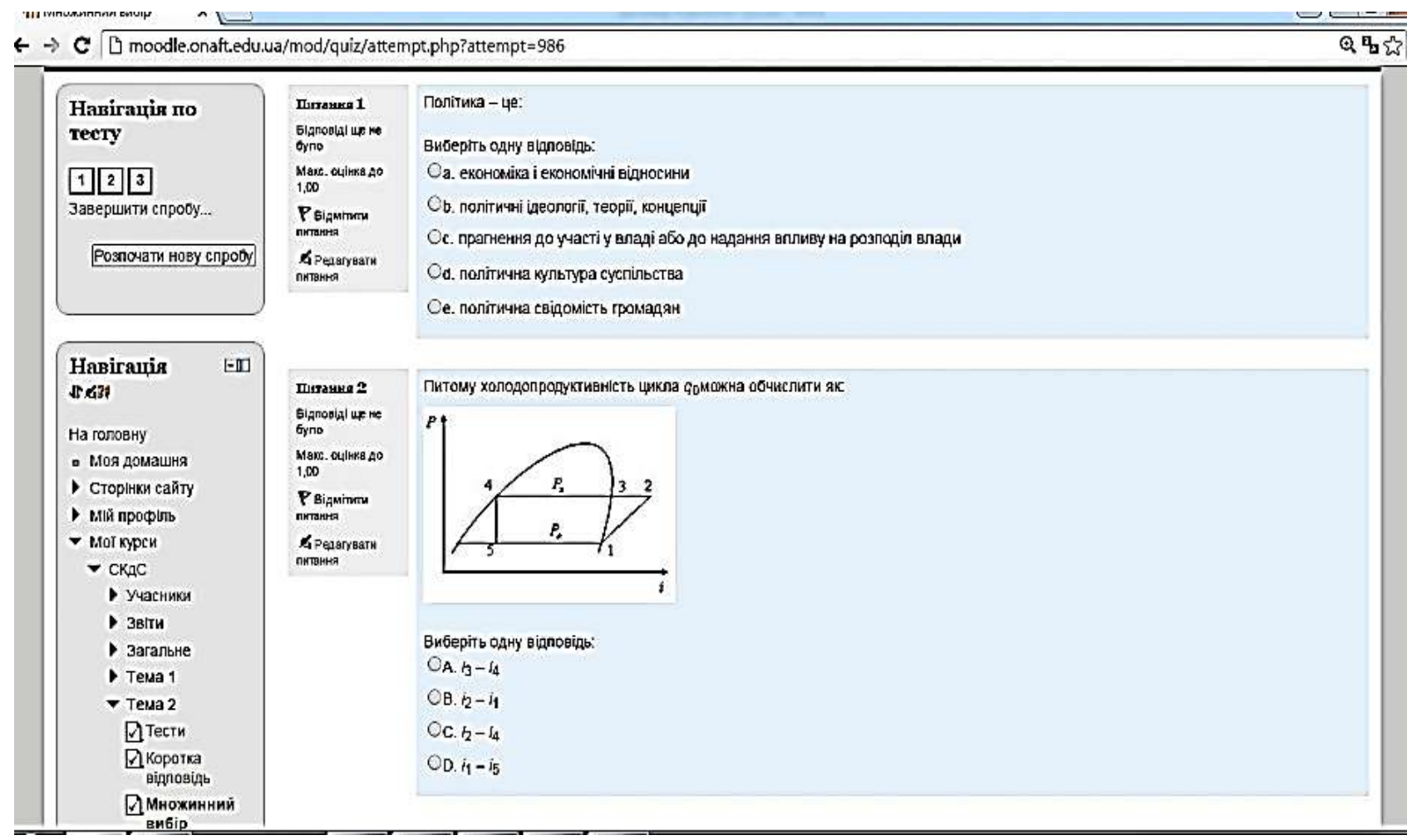

Рисунок 3 - Множинний вибір в тестовому завданні 
У теперішній час система підтримки дистанційного навчання ОНАХТ містить 285 дистанційних курсів, значний відсоток з яких наповнений необхідними навчальними матеріалами. Загалом зареєстровано 190 викладачів та більше 3000 студентів і ця кількість постійно збільшується.

\section{III. АНАЛІЗ ЯКОСТІ СТВОРЕНИХ ТЕСТІВ В СИСТЕMI MOODLE}

Система Moodle надає великі можливості щодо проведення перевірки знань [8]. Перш за все, це тестування, необхідне для проведення поточного контролю рівня знань студентів, а отже для їх підготовки до підсумкового контролю. Результати проведеного поточного контролю, а також дані про активність кожного студента (все це необхідно для встановлення «зворотного зв'язку» між викладачем та студентом, тобто інтерактивності в навчанні) відображаються в Журналі оцінок (рисунок 4).

Система Moodle дозволяє отримати дані успішності виконання кожного питання тесту для всіх слухачів курсу (рисунок 5), аналіз яких дозволяє викладачеві зробити висновок щодо ступені вдалості подання матеріалу і у разі потреби - підкорегувати його.

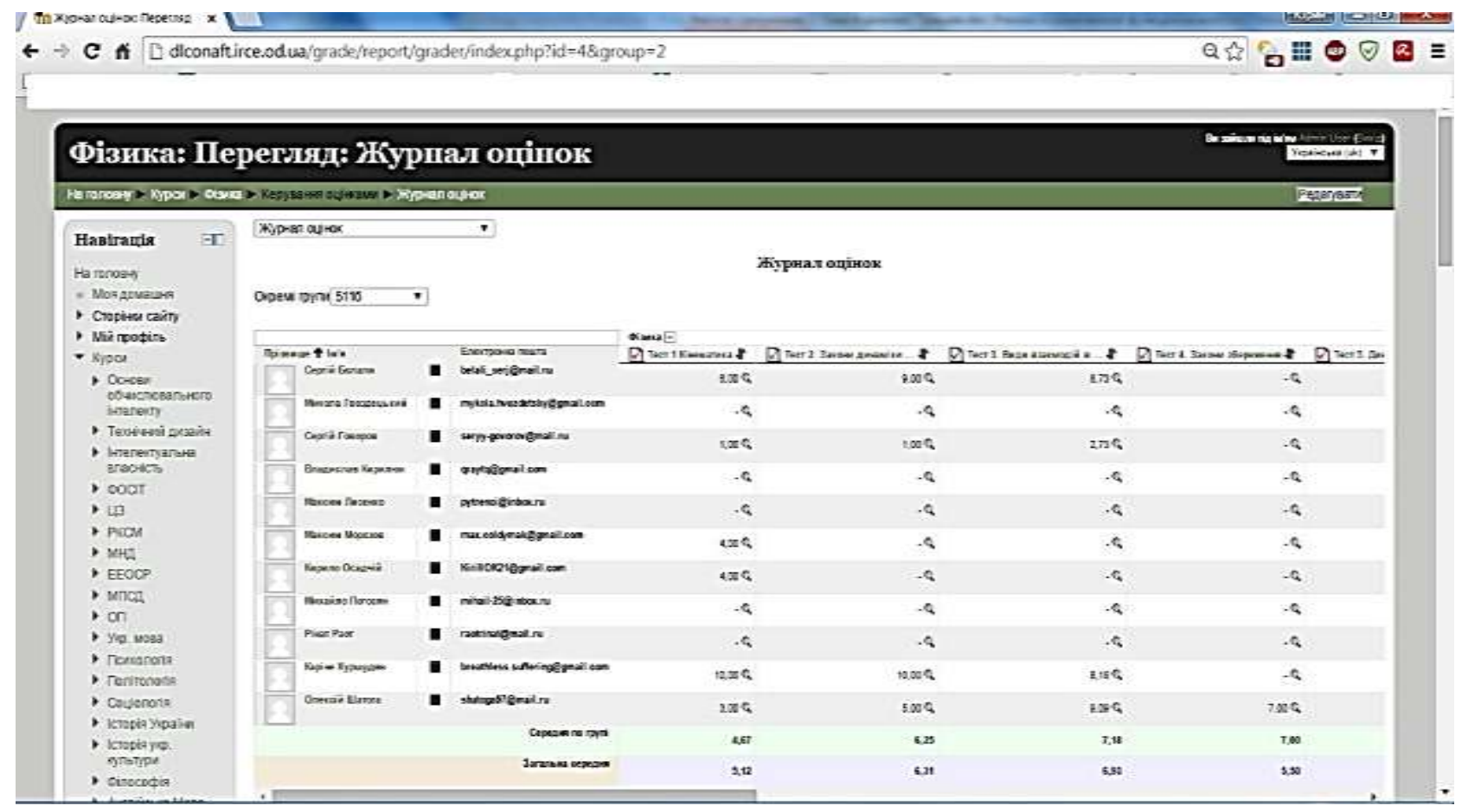

Рисунок 4 - Журнал оцінок

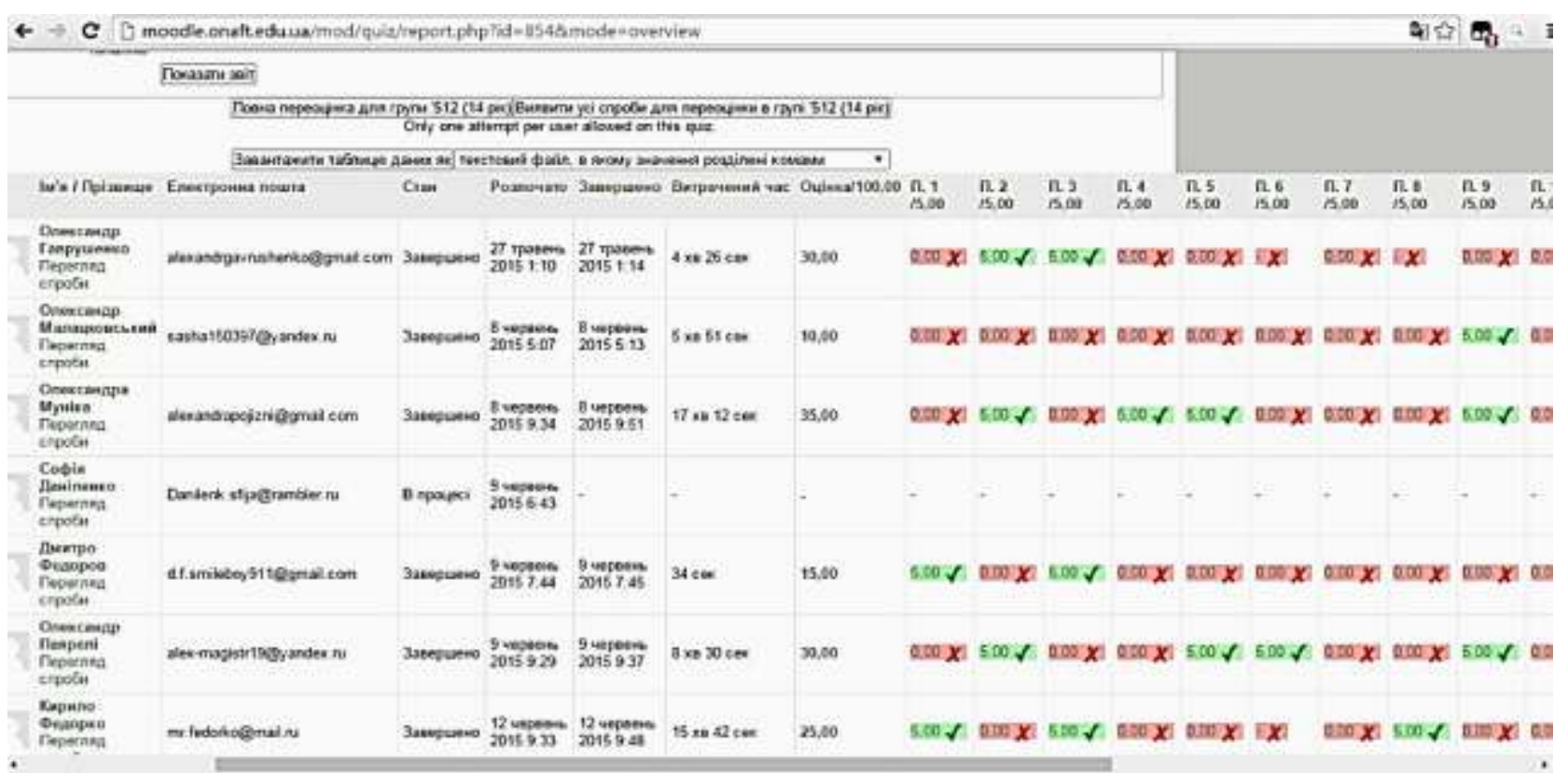

Рисунок 5 - Дані про проходження тесту користувачами 
Ще більш детальний аналіз тесту з точки зору його якості можна одержати, аналізуючи статистичні дані (рисунок 6). Система Moodle пропонує такий набір параметрів: середня оцінка, медіана оцінок для першої спроби, стандартне відхилення, значення асиметрії та ексцесу розподілу, коефіцієнт внутрішньої узгодженості, співвідношення (коефіцієнт) помилок, стандартна помилка. Зупинимось на деяких 3 цих параметрів більш детально.

Середня оцінка надається двох видів - по перших спробах та по всіх спробах. Медіана оцінок тільки для перших спроб. Стандартне (середнє квадратичне) відхилення показує розсіювання значень випадкової величини відносно її математичного сподівання. Значення асиметрії використовують для приблизної перевірки гіпотези про нормальність емпіричного розподілу. А саме, крива нормального розподілу зміщена вліво, якщо асиметрія від'ємна, та вправо у випадку додатних значень асиметрії (як в нашому випадку). Ексцес розподілу характеризує стрімкість зростання кривої розподілу порівняно з нормальною кривою. У випадку, коли ексцес додатній (як в нашому випадку), то крива теоретичного розподілу має вищу і «гострішу» вершину, ніж крива нормального розподілу; а ось якщо ексцес від'ємний, то крива теоретичного розподілу має нижчу і «плоскішу» вершину, ніж крива нормального розподілу. Один 3 найбільш важливих параметрів - коефіцієнт внутрішньої узгодженості - вказує на ступінь однорідності завдань тесту. Вважається, що якщо цей параметр вище 75\%, то тест $є$ задовільним. Якщо ж його значення нижче $64 \%$, тест в цілому є незадовільним, і необхідно вжити заходів з виправлення ситуації. Співвідношення (коефіцієнт) помилок для першої спроби показує, скільки є випадкових варіацій, при цьому чим менша їх кількість, тим кращий тест. Вважається, що значення цього параметру має бути нижче 50\% (в нашому випадку 37,23\%). Останній параметр списку - стандартна помилка для першої спроби - пов'язаний зі стандартним відхиленням, причому чим менша стандартна помилка, тим більш достовірною $є$ оцінка, яку одержано при тестуванні.

Крім того, система Moodle дозволяє виконати аналіз структури тесту (рисунок 7). Тут ми бачимо такі параметри: успішність (вказує, наскільки завдання $є$ складним для користувачів), стандартне відхилення, оцінка навмання, індекс та ефективність розрізнення [8].

C D moodle.onaft.edu.ua $/ \mathrm{mod} /$ quiz $/ \mathrm{report}$.php?id=928mode=statistics

Q.

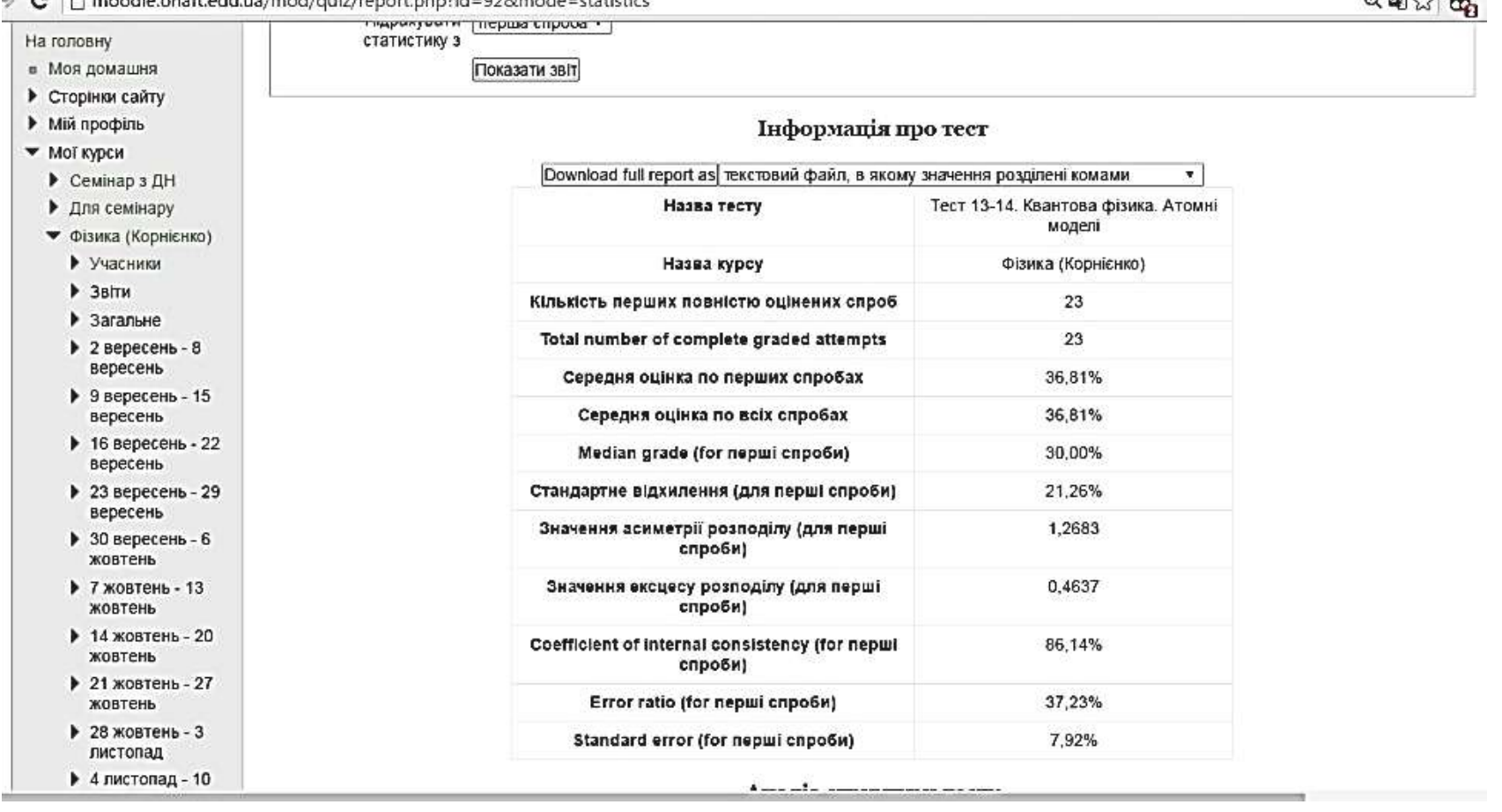

Рисунок 6 - Статистичні дані проходження тесту

\section{IV. ТЕСТУВАННЯ В МOODLE 3 ВИКОРИСТАН- НЯМ ЗОВНІШНІХ ОНЛАЙН-РЕСУРСІВ}

Bci, хто має свій курс в Moodle, в певний час замислюється над тим, чим урізноманітнити та зробити більш цікавим свій курс. Саме таку можливість надає вид діяльності Moodle «зовнішній засіб» у поєднанні з різноманітними онлайн-ресурсами.
Як приклад вдалого поєднання, розглянемо онлайн-pecypc LearningApps.org - безкоштовний сервіс Web 2.0, який містить блоки-вправи загального користування та дозволяє створювати тести, підготувати тренувальні вправи для закріплення матеріалу і подальшого використання у навчальному процесі. Даний ресурс підтримує розробки та містить банк вправ на 20 мовах світу, у тому числі й українською, англійською. 


\begin{tabular}{|c|c|c|c|c|c|c|c|c|c|c|c|}
\hline \multicolumn{12}{|c|}{ Анатіз етруктури тесту } \\
\hline \multicolumn{12}{|c|}{ 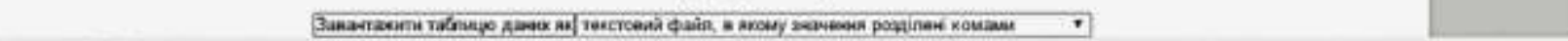 } \\
\hline $\begin{array}{c}\operatorname{mon} \\
\cos \end{array}$ & $\theta$ & F & Hasea neтsenn & Cnpo6 & Yeniluiken & Crama elaxnienen & Oulfesa nakuaresa & nomsestera aars & Eqerreana asea & $\begin{array}{l}\text { Posplanenнa } \\
\text { E }\end{array}$ & 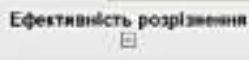 \\
\hline 1 & $\mathrm{E} \equiv$ & \& & Droestert & 23 & aros & 20.815 & $2000 \%$ & $3,33 \%$ & $1.94 \%$ & $1769 \mathrm{~s}$ & $2616 \%$ \\
\hline 2 & $\mathrm{t} \equiv$ & $\frac{a}{6}$ & Dotoedert & 23 & $30.43 \mathrm{~K}$ & $47.05 \%$ & $2000 \%$ & $3.33 \%$ & 4.035 & $53.45 \mathrm{~s}$ & $61.70 \%$ \\
\hline 3 & $\mathbf{i}$ & $\frac{9}{6}$ & Maca фorour & 23 & $47.83 \%$ & $51.05 \%$ & 200000 & $3,33 \%$ & $4.47 \mathrm{~s}$ & $61.45 \%$ & 87.445 \\
\hline 4 & $\mathrm{E}$ & $\frac{a}{4}$ & twnymas raara & 23 & 47.:13\% & $5108 \%$ & 200006 & $3,33 \%$ & 4.475 & $61.45 \%$ & $89.31 \%$ \\
\hline 5 & $\mathrm{E}$ & \& & Evesrix keametin & 23 & $56.52 \mathrm{~K}$ & $50.69 \%$ & 20000 & 3.336 & $402 \%$ & 48 oss & $7663 \%$ \\
\hline 6 & E & 4 & thenynte derona & 23 & 30.43\% & 47.05s & 20000 & $3.33 \%$ & $302 \%$ & $26.05 \mathrm{~s}$ & 30.185 \\
\hline 7 & $E$ & $\frac{9}{4}$ & 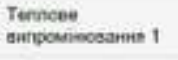 & 23 & $34.78 \%$ & $48.70 \%$ & $1667 \mathrm{~s}$ & $3.33 \%$ & $4.65 \%$ & $66.48 \%$ & $79.41 \%$ \\
\hline 8 & E & 2 & 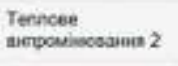 & 23 & $47.83 \%$ & 61005 & $2000 \%$ & $1,33 \%$ & 3218 & rears & 30.505 \\
\hline 9 & $\mathrm{E}$ & 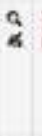 & $\begin{array}{l}\text { Terscoe } \\
\text { isponecosoave 3 }\end{array}$ & 23 & $43.46 \%$ & s0.095 & $2000 \%$ & $3.53 \%$ & $\begin{array}{l}\text { Negative } \\
\text { covarasce of } \\
\text { gade wh total } \\
\text { attengt grade } \\
\text { (3) }\end{array}$ & $-15.45 \%$ & $20.95 \%$ \\
\hline 10 & $\mathrm{E}$ & a & Trex caitna 1 & 23 & $30.43 \%$ & $47.05 \%$ & $2000 \mathrm{~s}$ & 3.356 & $302 \%$ & $2605 \%$ & $3010 \mathrm{~s}$ \\
\hline 11 & $\mathrm{t}$ & a & Trexenirna 2 & $\ldots$ & $\ldots \ldots$ & $\ldots$ & ...... & n.... & ..... & ..... & $\ldots$ \\
\hline
\end{tabular}

Рисунок 7 - Аналіз структури тесту

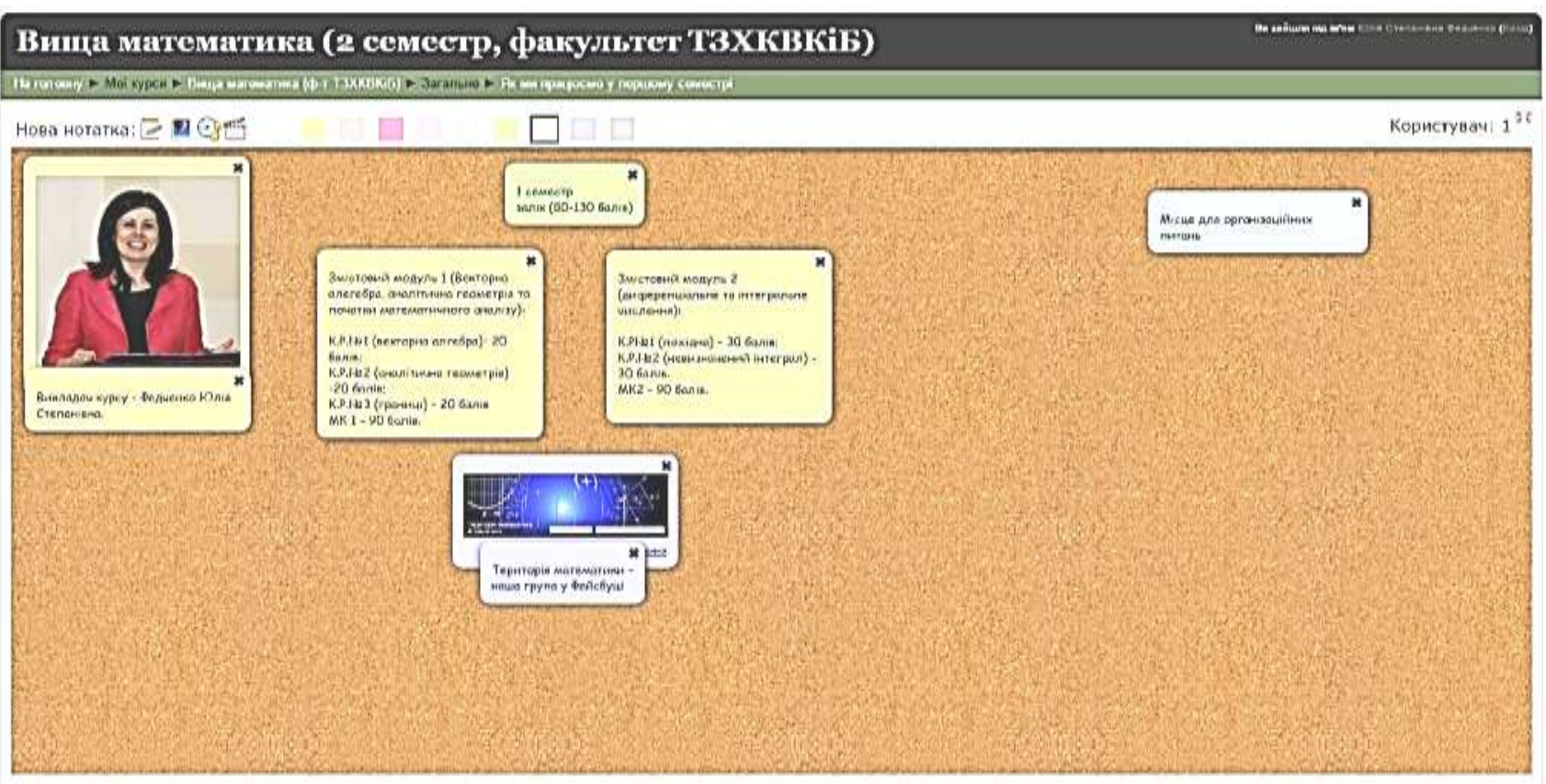

Рисунок 8 - Дошка оголошень

Існують наступні шаблони для створення власних вправ:

- знайди пару;

- класифікація;

- числова пряма;

- просте упорядкування;

- фрагменти зображення;

- введення власної відповіді;

- аудіо- та відео-контент;

- колекція вправ (одна тема та декілька різних вправ за підтемами);

- знайти на карті;
- заповнити пропуски та інші.

Окрім вищезазначених шаблонів $є$ можливість використання дошки оголошень (дозволяє викладати тестові, аудіо-, відео- повідомлення та різні картинки) (рисунок 8), створення нотатків, проведення голосування.

У залежності від поставлених цілей та завдань, викладач курсу може обирати засоби перевірки знань і цим вдосконалювати свій курс.

При створенні курсу «Вища математика» в Moodle було використано ресурс LearningApps.org для створення різноманітних вправ [6]: 
1) на відповідність відео контенту, що дає можливість вставити міні-тести як в середині відео, так і наприкінці, додати різноманітні мітки протягом усього відео-матеріалу;

2) на класифікацію, зокрема, для допомоги визначення типів диференціальних рівнянь першого та другого порядків (рисунок 9);
3) на введення текстових відповідей до графічних зображень, що дозволяє швидко вивчити назви об'єктів дослідження.

Важливим і нелегким завданням у формуванні курсу «Вища математика» є збереження зацікавленості протягом усього часу навчання і в нагоді стають саме онлайн-сервіси.

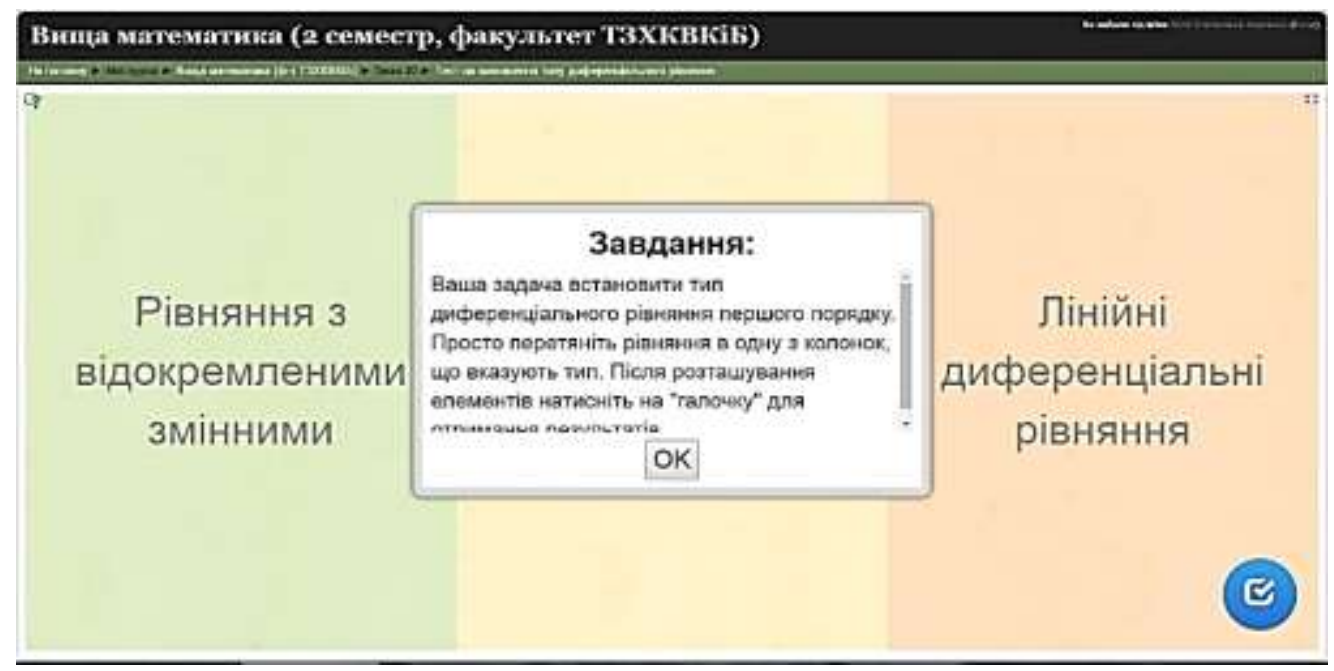

Рисунок 9 - Вправи на класифікацію

\section{ВИСНОВКИ}

Застосування технологій дистанційного навчання у навчальному процесі в ОНАХТ розкриває можливості позитивного впливу на підвищення рівня якості освіти та є невід'ємним елементом для отримання студентами академії сучасної якісної освіти. В статті розкривається зміст параметрів, які застосовуються для аналізу тестових завдань в системі Moodle, описані критерії показників якості тестових завдань. Поєднання можливостей Moodle та онлайн-сервісів гарантує удосконалення будь-якого курсу, дає шанс зробити його неповторним і найпродуктивнішим. Результат залежить від викладача та можливості постають дуже широкі, якщо врахувати кількість таких навчальних сервісів.

\section{ЛІТЕРАТУРА}

1. Bykov V. Innovative models of education and training of skilled personnel for high industries in Ukraine / Valeriy Bykov, Mariya Shyshkina / Information technologies in education: Scientific journal. Issue 15. Kherson: KSU, 2013. - Pp. 19-29.

2. «Положення про дистанційне навчання», затверджене Міністерством освіти і науки України наказом № 466 від 25 квітня 2013 року. - [Електронний ресурс]. - Режим доступу: http://osvita.ua/legislation/ Dist_osv/2999 (14.04.2016).

3. Офіційний сайт СДО Moodle [Електронний ресурс]. - Режим доступу: http://www.moodle.org. 14.04.2016
4. Паращенко Л.І., Леонський В.Д., Леонська Г.І. Тестові технології у навчальному закладі: Метод. посібник / Л.І. Паращенко, В.Д. Леонський, Г.І. Леонська; Наук. ред. О.І. Ляшенко. - К.: [ТОВ «Майстерня книги»], 2006. - 217 с.: іл. 21.

5. Брянкин К.В., Вылегжанина И.А. Тестирование как технология контроля качества самостоятельной работы студентов вуза // Современные проблемы науки и образования. - 2013. - № 5. - [Електронний pecypc]. - Режим доступу: http://www.scienceeducation.ru/pdf/2013/5/658.pdf (15.04.2016).

6. Корніснко Ю. К., Федченко Ю. С. Про тестування в Moodle 3 використанням зовнішніх online-pecyрсів. Тези доповідей Четвертої міжнародної науковопрактичної конференції «MoodleMoot Ukraine 2016. Теорія і практика використання системи управління навчанням Moodle». (Київ, КНУБА, 19-20 травня 2016 р.). - К.: КНУБА, 2016.- С. 27.

7. Корніснко Ю. К., Трішин Ф. А. Організація самостійної роботи студентів 3 використанням системи дистанційного навчання Moodle. Матеріали 47 науково-методичної конференції «Перспективи розвитку науково-методичного забезпечення для самостійного вивчення дисциплін та їх окремих розділів». (Одеса, OHAXT, 4-5 квітня 2016 р.). - О.: ОНАХT, 2016. C. 173-180.

8. Сергієнко В.П. Використання вбудованої системи аналізу тестових завдань в LCMS Moodle / Л.О.Кухар, О.В.Галицький, П.В.Микитенко //Інформаційні технології і засоби навчання. - 2014. - Т. 41, вип. 3. - С. 196-208. - Режим доступу: http://nbuv.gov.ua/ UJRN/ITZN_2014_41_3_21 (14.04.2016). 
Y. K. Когпіепко, Y. S. Fedchenko, F. A. Trishyn

Odesa National Academy of Food Technologies, Kanatna str., 112, Odesa, 65039, Ukraine

$\triangle$ e-mail: yurikkorn@ gmail.com, ORCID: orcid.org/0000-0002-0973-3927

\section{APPLICATION OF DISTANCE TECHNOLOGIES AS A WAY TO IMPROVE THE QUALITY OF EDUCATION}

The article dwells upon the experience of implementation and application of support learning based on Moodle, which has been created and applied in the Odessa National Academy of Food Technologies since 2014. The role provided for the distance education programs is emphasized, the benefits of system based on Moodle are proved in a well-argued manner: the system is freely distributed, simple to install on any platform that supports PHP; it is spread among many institutions of higher education; it has a multilingual interface (including supported Ukrainian, English), designed to meet the advances of modern pedagogy (focus is on the interaction between the students, forum discussion); has a simple, "easy", efficient, compliant web-based interface. Besides, the system provides great possibilities to conduct assessment of knowledge. It is noted that at this stage of application of the system based on Moodle is used in the academy to support traditional education as intramural and extramural forms of study, including the organization of independent work of students. Distance Learning Center website was developed by e-mail: http://moodle.onaft.edu.ual, requirements document, the Center operates by, were prepared and approved. Along with installing Moodle software environment it was made possible to design distance learning courses on server hosting registration. It is noted that the present system of distance learning of ONAFT contains 285 distance learning courses filled with the necessary teaching materials. In general, 190 teachers are recorded as well as more than 3,000 students of all faculties of the academy and this number is growing. The requirements that developers of distance learning courses must consider are described. Examples of already created distance learning courses, their composition and characteristics are given. Some of them are offered teachers as a model for creating your own courses. Special attention is paid to the test control of knowledge required for current control of students' knowledge. The main types of tests, such as Multiple choice, Matching, Numerical, Essay, due to their features and settings are considered. Hereafter the mechanism of creation of these types of tests is explained on examples. Considerable attention is paid to the Journal of levels, which contains test results. Quality of creation of tests is analyzed, quality parameters are provided, the means to improve this quality are offered. The latest can be done by the application of external resources in the system Moodle, for example, by applying of such online resource as LearningApps.org.

Keywords: Distance Learning; Informatization of Education; Computerization of Education; Test control; System Moodle; Analysis of Test Structure.

\section{REFERENCES}

1. Valeriy Bykov, Mariya Shyshkina (2013). Innovative models of education and training of skilled personnel for high industries in Ukraine. Information technologies in education, iss. 15, 19-29. Available at: http://ite.kspu.edu/ en/issue-15/p-19-29 (Date of access: 14 April 2016).

2. «Polozhennia pro dystantsiine navchannia», zatverdzhene naazom MONU No 46625 April 2013. [Electronic source] Available at: http://osvita.ua/legislation/ Dist_osv/2999/. (Date of access: 14 April 2016) (in Ukrainian).

3. Moodle. [Electronic source]. Available at: http://www.moodle.org. (Date of access:14 April 2016)

4. Paraschenko, L. I., Leonskii, V. D., Leonska, G. I. (2006). Testovi tekhnologii u navchalnomu zakladi. Kyiv: TOV «Maisternia knygy», 217 p. (in Ukrainian).

5. Briankin, K. V., Vylegzhanina, I. A. (2013). Testing the technology of quality control of high school students independent work. Modern problems of science and education, No. 5 [Electronic source]. Available at: http://www.science-education.ru/pdf/2013/5/658.pdf.

(Date of access: 14 April 2016) (in Russian).

6. Kоrnienкo, Y. K., Fedchenko, Y. S. (2016). Pro testuvannia v Moodle z vykorystanniam zovnishnikh onlineresursiv. Proc. of IV International scientific-practical conference «MoodleMoot Ukraine 2016. Teoriia i praktyka vykorystannia systemy upravlinnia navchanniam Moodle». Kyiv, KNUBA, 19-20 May 2016, p. 27. Available at: http://2016.moodlemoot.in.ua/pluginfile.php/ 2559/mod_resource/content/2/Тези\%20MoodleMoot2016.pdf (Date of access: 14 June 2016) (in Ukrainian).

7. Kornienкo, Y. K., Trishyn, F. А. (2016). Organizatsiia samostiinoi roboty studentiv z vykorystanniam systemy dystantsiinogo navchannia Moodle. Proc. of 47 naukovometodychnoi konferentsii «Perspektyvy rozvytku naukovo-metodychnogo dlia samostiinogo vyvchennia dystsyplin ta ikh okremykh rozdiliv». Odesa, ONAFT, 4-5 April 2016, pp. 173-180. Available at: http://mv.onaft.edu.ua/ download/konfer/45606.pdf (Date of access: 14 June 2016) (in Ukrainian).

8. Volodymyr P. Serhiienko, Liudmyla O. Kukhar, Oleksandr V. Halytskyi, Pavlo V. Mykytenko (2014). Use of integrated system of analysis of tests' tasks in LCMS Moodle. Information technologies and learning tools, vol. 41 iss. 3, 196-208. Available at: http://nbuv.gov.ua/UJRN/ ITZN_2014_41_3_21 (Date of access: 14 April 2016) (in Ukrainian).

Received 15 June 2016 Approved 01 July 2016 Available in Internet 31 August 2016 